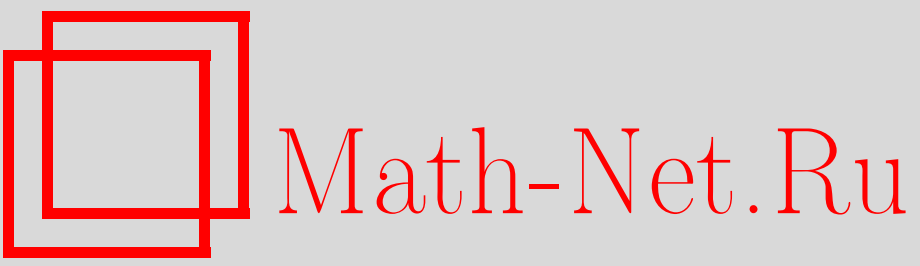

В. Ф. Молчанов, Тамбовская школа-семинар по гармоническому анализу, $У M H$, 1997, том 52, выпуск 6, 216

DOI: https://doi.org/10.4213/rm1611

Использование Общероссийского математического портала Math-Net.Ru подразумевает, что вы прочитали и согласны с пользовательским соглашением

http://www.mathnet.ru/rus/agreement

Параметры загрузки:

IP : 54.89 .56 .158

26 апреля 2023 г., 13:10:57 


\section{ТАМБОВСКАЯ ШКОЛА-СЕМИНАР ПО ГАРМОНИЧЕСКОМУ АНАЛИЗУ}

С 26 по 31 августа 1996 года в Тамбове была проведена международная летняя школа-семинар "Гармонический анализ на однородных пространствах". В работе школы участвовало около 50 математиков из России (Москва, Тамбов, Омск, Оренбург, Обнинск, Петрозаводск, Рязань), Украины (Киев, Харьков), Франции, Нидерландов. Среди участников было много молодых математиков, в том числе и студентов.

Основное содержание работы школы было связано с гармоническим анализом на симметрических пространствах (представления групп движений, в частности, канонические представления; квантование; инвариантные подпространства и инвариантные алгебры функций; приближения функций и др.), но в целом тематика лекций и докладов оказалась достаточно широкой: от классических рядов Фурье-Якоби до представлений бесконечномерных групп, $C^{*}$-алгебр, *-алгебр, "идемпотентной математики" и некоторых структурных и классификационных задач.

Работа школы была организована следующим образом. Было прочитано 10 небольших курсов лекций, кроме того, участникам школы была предоставлена возможность выступить с докладами о своих результатах. Вот список циклов лекций.

1. Э. Б. Винберг (Москва), О расположении редуктивных подгрупп в редуктивной группе.

2. М. И. Граев (Москва), Особые представления групп Ли и связанные с ними представления групп токов.

3. Г. ван Дейк (Лейден), Канонические представления.

4. Р. С. Исмагилов (Москва), Локальная коммутативность и локальные алгебры Ли.

5. Г. Л. Литвинов (Москва), Неприводимые неунитарные представления нильпотентных групп Ли.

6. Г. Л. Литвинов (Москва), Идемпотентная математика и представления.

7. В. Ф. Молчанов (Тамбов), Квантование на симплектических симметрических пространстBax.

8. Ю.А. Неретин (Москва), Дискретные спектры и особые унитарные представления.

9. В.-Б. К. Рогов (Москва), Функции Бесселя с теоретико-групповой точки зрения.

10. Г. Роос (Пуатье), Йордановы тройные системы, минимальные многочлены и приложения.

Иногородние участники школы были размешены в гостинице в живописном месте неподалеку от Тамбова (на берегу реки Цны, рядом с сосновым лесом). Для участников школы была организована поездка в музей С. В. Рахманинова в Ивановке, экскурсия по городу и концерт университетского хора (рук. В.В. Козляков).

Школа-семинар была проведена на базе Тамбовского государственного университета им. Г.Р. Державина (ректор В.М. Юрьев), она была поддержана грантом Российского фонда фундаменталшных исследований, помощь была оказана также французским фондом "Pro Mathematika". Материалы школы будут опубликованы в выпусках журнала "Вестник Тамбовского университета", электронная почта для контактов: molchanov@math-univ.tambov.su.

B. Ф. Молчанов 